\title{
A thymidine kinase-deleted bovine herpesvirus 5 establishes latent infection but reactivates poorly in a sheep model ${ }^{1}$
}

\author{
Gustavo C. Cadore², Marcelo Weiss², Deniz Anziliero², Mário Celso S. Brum³, \\ Rudi Weiblen ${ }^{2}$ and Eduardo F. Flores ${ }^{2 *}$
}

\begin{abstract}
Cadore G.C., Weiss M., Anziliero D., Brum M.C.S., Weiblen R. \& Flores E.F. 2013. A thymidine kinase-deleted bovine herpesvirus 5 establishes latent infection but reactivates poorly in a sheep model. Pesquisa Veterinária Brasileira 33(3):331-338. Departamento de Medicina Veterinária Preventiva, Universidade Federal de Santa Maria, Camobi, Santa Maria, RS 97105-900, Brazil. E-mail: eduardofurtadoflores@gmail.com

The ability of thymidine kinase $(t k)$-deleted recombinant bovine herpesvirus 5 (BoHV$-5 t k \Delta$ ) to establish and reactivate latent infection was investigated in lambs. During acute infection, the recombinant virus replicated moderately in the nasal mucosa, yet to lower titers than the parental strain. At day 40 post-infection (pi), latent viral DNA was detected in trigeminal ganglia (TG) of all lambs in both groups. However, the amount of recombinant viral DNA in TGs was lower (9.7-fold less) than that of the parental virus as determined by quantitative real time PCR. Thus, $t k$ deletion had no apparent effect on the frequency of latent infection but reduced colonization of TG. Upon dexamethasone (Dx) administration at day $40 \mathrm{pi}$, lambs inoculated with parental virus shed infectious virus in nasal secretions, contrasting with lack of infectivity in secretions of lambs inoculated with the recombinant virus. Nevertheless, some nasal swabs from the recombinant virus group were positive for viral DNA by PCR, indicating low levels of reactivation. Thus, BoHV-5 TK activity is not required for establishment of latency, but seems critical for efficient virus reactivation upon Dx treatment.
\end{abstract}

INDEX TERMS: BoHV-5, recombinant, TK, latency, qPCR.

RESUMO.- [Recombinante do herpesvírus bovino tipo 5 com deleção na timidina quinase estabelece infecção latente porém reativa ineficientemente em ovinos.] A capacidade de um recombinante do herpesvírus bovino tipo 5 com deleção no gene da timidina quinase (BoHV-5tk $\Delta$ ) em estabelecer e reativar infecção latente foi investigada em cordeiros. Durante a infecção aguda, o vírus recombinante replicou na mucosa nasal em títulos moderados, porém menores do que os da cepa parental. Aos 40 dias pós-infecção (pi) DNA viral latente foi detectado no gânglio trigêmeo (TG) de todos os cordeiros em ambos os grupos. No entanto, a quantidade de DNA do vírus recombinante nos TGs foi 9,7 vezes menor do que do vírus parental, segundo deter-

\footnotetext{
${ }^{1}$ Received on October 10, 2012.

Accepted for publication on January 30, 2013.

${ }^{2}$ Setor de Virologia, Departamento de Medicina Veterinária Preventiva (DMVP), Centro de Ciências Rurais (CCR), Universidade Federal de Santa Maria (UFSM), Santa Maria, RS 97105-900, Brazil. *Corresponding author: eduardofurtadoflores@gmail.com

${ }^{3}$ Faculdade de Veterinária, Universidade do Pampa (Unipampa), BR 472 Km 585, Uruguaiana, RS 97500-970, Brazil.
}

minação por PCR em tempo real. Assim, a deleção do gene tk (timidina quinase) não produziu efeito aparente sobre a frequência da infecção latente, porém reduziu a colonização do TG. Após a administração de dexametasona (Dx) no dia 40pi, os cordeiros inoculados com o vírus parental excretaram partículas virais infecciosas, contrastando com a falta de infectividade nas secreções nasais dos animais inoculados com o vírus recombinante. Entretanto, alguns suabes nasais dos cordeiros do grupo do vírus recombinante foram positivos para o DNA viral por PCR, indicando baixos níveis de reativação. Assim, a atividade da enzima timidina quinase não é requerida para o estabelecimento de latência pelo BoHV-5, mas parece fundamental para reativação eficiente da infecção latente após tratamento com Dx.

TERMOS DE INDEXAÇÃO: BoHV-5, recombinante, TK, latência, qPCR.

\section{INTRODUCTION}

Bovine herpesvirus type 5 (BoHV-5) is an enveloped DNA virus classified within the family Herpesviridae, subfamily 
Alphaherpesvirinae, genus Varicellovirus (Roizman et al. 1992). The agent is associated with meningoencephalitis in cattle, a disease frequently described in Argentina (Perez et al. 2003) and Brazil, where many outbreaks are reported every year (Salvador et al. 1998, Rissi et al. 2008). BoHV-5 is closely related to bovine herpesvirus 1 (BoHV-1), the agent of bovine infectious rhinotracheitis and vulvovaginitis/balanoposthitis (Kahrs 2001). BoHV-5 is highly neurovirulent in cattle and in animal models, a property that distinguishes it from BoHV-1 (Belknap et al. 1994, Chowdhury et al. 1997, Vogel et al. 2003). Like other alphaherpesviruses, these viruses establish latent infections in sensory nerve ganglia and can be reactivated spontaneously or by corticosteroid administration (Rock 1994, Vogel et al. 2003).

The BoHV-5 genome is a linear double-stranded DNA molecule of approximately $138 \mathrm{~kb}$ in length and encodes at least 70 gene products (Delhon et al. 2003). By analogy with other alphaherpesviruses, approximately half of viral-encoded products are non-essential (NE) for virus replication in tissue culture (Delhon et al. 2003). Deletions of individual NE genes - especially the gene encoding the enzyme thymidine kinase (TK) - have been used to produce attenuated BoHV-1 strains for use in vaccines (Kit 1985, Chowdhury 1996, Kaashoek et al. 1996). Herpesvirus-encoded TK is an enzyme involved in the metabolism of deoxyribonucleotides, an activity necessary for viral DNA synthesis and genome replication in non-dividing cells such as neurons (Tenser 1991). Usually, $t k$ gene deletion leads to deficient virus replication in neurons and reduced neurovirulence of human and animal alphaherpesviruses (Coen et al. 1989, Mengeling 1991, Tenser 1991, Ferrari et al. 2000). BoHV-1 mutants lacking TK activity are attenuated to different levels (Kit 1985, Chowdhury 1996, Kaashoek et al. 1996), and a tk deletion BoHV-5 mutant was shown to be attenuated for rabbits (Silva et al. 2010) and calves (Santos et al. 2011).

Although herpesvirus-encoded TK activity is required for virus replication in neurons, it is not necessary for the establishment of latency by human and animal alphaherpesviruses (Tenser et al. 1979, Coen et al., 1989, Volz et al. 1992, Kaashoek et al. 1996, Chen et al. 2004). In contrast, TK activity is required for efficient reactivation such the ability of TK-defective viruses to reactivate latency is drastically reduced, if not abolished (Coen et al. 1989, Volz et al. 1992, Kaashoek et al. 1996, Ferrari et al. 1998, Chen et al. 2004). Regardless, some conflicting results have been reported, and reactivation of TK-negative pseudorabies virus (PRV, Mengeling 1991) and BoHV-1 mutants has been reported (Whetstone et al. 1992). In any case, it generally accepted that TK-defective alphaherpesviruses do not reactivate - or reactivate poorly - from sensory nerve ganglia (Tenser et al. 1979, Coen et al. 1989, Chen et al. 2004).

Our group described the construction of a $t k$-deleted recombinant BoHV-5 strain (BoHV-5tk $\Delta$ ) as a part of a vaccine project (Brum et al. 2010a). The recombinant was attenuated for calves and rabbits, yet it was capable of establishing latent infection in the trigeminal ganglia (TG) of both species (Santos et al. 2011, Silva et al. 2010). The recombinant virus reactivated poorly in calves upon dexa- methasone (Dx) treatment (Santos et al. 2011) and did not reactivate in rabbits (Silva et al. 2010). In the present study, we conducted a more comprehensive study on the biology of latent infection by BoHV-5tk $\Delta$. We used lambs as a model since rabbits are too susceptible to BoHV-5 neurological disease and most inoculated animals die during acute infection (Caron et al. 2002, Flores et al. 2009). In contrast, lambs are susceptible to acute and latent BoHV-5 infection yet and are relatively resistant to neurological disease (Silva et al. 1999, Cadore et al. 2011). In addition to investigate the latency-reactivation cycle, we used real time PCR (qPCR) to compare the amount of latent viral DNA in TGs of lambs inoculated with the recombinant BoHV-5tk $\Delta$ versus the parental strain.

\section{MATERIALS AND METHODS}

Experimental design. Lambs were inoculated intranasally (IN) with the parental virus (BoHV-5 SV-507/99, n=14) or with the recombinant (BoHV-5tk $\Delta, \mathrm{n}=14$ ) and submitted to clinical, virological and serological monitoring during acute infection. At day 40 post-inoculation (pi), 10 animals of each group were euthanized for tissue collection. Total DNA extracted from TGs was submitted to a nested-PCR for detection and real time quantitative PCR (qPCR) for quantification of latent viral DNA. The remaining lambs ( $n=4$ from each group) were submitted to Dx treatment and monitored thereafter for virus shedding and seroconversion.

Viruses and cells. The recombinant virus lacking the $t k$ gene (BoHV-5tks) was constructed out of a well characterized Brazilian BoHV-5 strain (Brum et al. 2010a). The parental strain (SV$507 / 99$ ) was isolated from a cow with neurological disease in Southern Brazil and had its entire genome sequenced (Delhon et al. 2003). All procedures of virus multiplication, isolation and serological tests were performed in a MDBK-derived cell line named CRIB (ATCC-CRL 11883). Cells were maintained in minimum essential medium (MEM, Invitrogen, Brazil), supplemented with $10 \%$ fetal bovine serum (Nutricell, Brazil), $100 \mathrm{U} / \mathrm{mL}$ of penicillin and $100 \mu \mathrm{g} / \mathrm{mL}$ of streptomycin (Nutricell, Brazil). The two viruses were used at passage \# 6 in CRIB cells.

In vitro growth kinetics. Prior to animal inoculation, we investigated the ability of both viruses to replicate in cultured cells of ovine origin. The one step growth curve was performed in primary lamb testicle cells (passage \# 8), using CRIB cells as controls, according to Brum et al. (2010a). Cell monolayers in 6-well plates were inoculated with either virus at a multiplicity of infection (m.o.i.) of 5 and the cells were further incubated for $2 \mathrm{~h}$ at $37^{\circ} \mathrm{C}$ to allow virus penetration. The inoculum was then removed, and the cells were washed twice with MEM and overlaid with fresh MEM supplemented with 5\% fetal bovine serum. At intervals after virus inoculation $(0,6,12,18,24$ and $30 \mathrm{~h})$ aliquots of culture supernatants were harvested and submitted to virus quantitation by limiting dilution. Virus titers were calculated according to Reed and Muench (1938) and expressed as $\log _{10}$ median tissue culture infectious dose per mililiter $\left(\mathrm{TCID}_{50} / \mathrm{ml}\right)$.

Animals, virus inoculation and monitoring. Twenty eight Pollwarth lambs of both genders, aging 4 to 6 months, were randomly allocated in two groups of 14 animals each and inoculated with either virus (parental or recombinant). Each animal received an inoculum of $2 \mathrm{~mL}$, divided in the two nostrils, containing a total dose of $10^{6.7} \mathrm{TCID}_{50} / \mathrm{mL}$. After inoculation, animals were monitored clinically on a daily basis and nasal swabs for virus isolation and quantification were collected up to day 15 pi; blood for serology was collected at days 0 and 40 pi. At that day, 10 animals of each group were euthanized for tissue collection. TGs were 
collected aseptically and stored at $-80^{\circ} \mathrm{C}$ until use. The remaining lambs ( $n=4$ for each group) were then submitted to five daily intramuscular administrations of dexamethasone (Dx, $0.2 \mathrm{mg} / \mathrm{kg} /$ day; Decadronal $®$, Aché, Brazil) and monitored as described for acute infection. Swabs for virus isolation and quantification were collected up to day 15 post Dx treatment (pDx) and blood for serology was collected at day $15 \mathrm{pDx}$.

All procedures of animal handling and experimentation were performed under veterinary supervision and according to recommendations by the Brazilian Committee on Animal Experimentation (COBEA; law \# 6.638 of May 8, 1979). The animal experiments were approved by the Institutional Ethics and Animal Welfare Committee (UFSM, approval \# 96/2010 of January 18, 2011).

Sample processing. Viral isolation and quantification in nasal swabs were performed in CRIB cells according to standard protocols (Diel et al. 2007). Virus titers in nasal secretions were expressed as $\log _{10} \mathrm{TCID}_{50} / \mathrm{ml}$. Sera obtained at days 0 and $40 \mathrm{pi}$; and at day $15 \mathrm{pDx}$ were submitted to a standard virus neutralizing assay (VN) for neutralizing antibodies, testing two-fold dilutions of sera against 100-200 TCID $_{50}$ of virus (Diel et al. 2007). Geometric mean titers (GMT) of neutralizing antibodies of each group were calculated according to Thrusfield (2005).

DNA extraction and PCR. After cleaning, TGs were minced with a razor blade and submitted to total DNA extraction using phenol-chloroform protocol (Vogel et al. 2003). DNA extraction of nasal swabs was performed using DNAzol@ Reagent (Invitrogen, Carlsbad, CA, USA) according to the manufacturer's protocol. After extraction, DNA was solubilized in Tris-EDTA $(80 \mu \mathrm{L})$ and stored at $-80^{\circ} \mathrm{C}$ until testing. DNA concentration was measured by ultra violet light (UV) absorbance at $260 \mathrm{~nm}$. Total DNA was submitted to a nested PCR using two set of primers of the glycoprotein B (gB) amplified according Diel et al. (2007). External primers, used in first reaction were - forward: 5'-CCAGTCCAGGCAACCGTCAC-3' and reverse: 5'-CTCGAAAGCCGAGTACCTGCG-3'. The internal primers, used in second reaction were - forward: 5'-GTGGTGGCCTTTGACCGCGAC-3' and reverse: 5'-GCTCCGGCGAGTAGCTGGTGTG-3'. The first PCR reaction amplifying a 444 bp DNA fragment and the second reaction results in a $294 \mathrm{bp}$ amplicon. The PCR products were added with $3 \mu \mathrm{L}$ GelRed ${ }^{\circledR}$ (Biotium, Inc., CA, USA) and analyzed under UV light after electrophoresis in an $1 \%$ agarose gel. Total DNA extracted from the brain of a control non-infected lamb, and from a calf with acute BoHV-5 infection was used as negative and positive controls, respectively.

For swabs, nasal secretions obtained from an uninfected lamb were tested in parallel as negative control. PCR for $t k$ gene applied on nasal swabs used the following primers: forward: 5'-GACGTCGTGACCCTCGTGTTTG-3' and reverse: 5'-TAGGAAGGCGCACGTGTTCG- 3'. The PCR amplifying a 285 pb DNA fragment and was carried out in a $25 \mu \mathrm{L}$ volume containing $1 \mathrm{X}$ PCR buffer, $10 \mathrm{mM}$ deoxyribonucleotides, $10 \mathrm{mM}$ of each primer, 2.5 units Taq polymerase, $1.5 \mathrm{mM} \mathrm{MgCl}_{2}, 10 \%$ DMSO, and 100ng DNA as template. The PCR conditions consisted of initial denaturation at $94^{\circ} \mathrm{C}$ for 5 min followed by 35 cycles at $94^{\circ} \mathrm{C}$ for $45 \mathrm{~s}, 60^{\circ} \mathrm{C}$ for $30 \mathrm{~s}$ and $72^{\circ} \mathrm{C}$ for $45 \mathrm{~s}$, and final extension of $10 \mathrm{~min}$ at $72^{\circ} \mathrm{C}$. The PCR to gB gene was the same as described previously.

Real-time PCR (qPCR). Total DNA extracted from TGs was submited to a qPCR analysis to estimate and compare the amount of latent DNA in lambs infected with the parental and recombinant virus. The qPCR was conducted in an StepOnePlus (Applied Biosystems, Foster City, CA) with Power SYBR $囚$ Green PCR Master Mix (Applied Biosystems). Two sets of primers were used: one set for ovine GAPDH gene (forward: 5'-TGTTCCAGTATGATTCCACCC-3' and reverse: 5'-TCCACCACCCTGTTGCTGTA-3') and another for BoHV-5 glycoprotein G (gG) gene (forward: 5'-GCCC-
TGGTTGTCCTAGACATG-3' and reverse: 5'-CGTTCCCCGTGCAGTTAAAG-3'). The qPCR was performed in $25 \mu \mathrm{L}$ volume reaction containing, $12.5 \mu \mathrm{L}$ of SYBR $®$ Green PCR Master Mix, $5 \mathrm{mM}$ of each primer and $100 \mathrm{ng}$ template of total DNA. Thermal cycling parameters $\left(10 \mathrm{~min}\right.$ at $95^{\circ} \mathrm{C}$ and 40 cycles of $15 \mathrm{~s}$ at $95^{\circ} \mathrm{C}, 1 \mathrm{~min}$ at $60^{\circ} \mathrm{C}$ ) were used to amplify each reaction. All samples were run in duplicates and melting-curve analysis was performed to verify product identity. Before the relative quantification analysis, a computer program (LinRegPCR, version 11.4) was used to normalize the Ct results with the amplification efficiency. For quantification analysis just samples that had PCR efficiency next to 2 $( \pm 0.1)$ and correlation next to $1( \pm 0.001)$ was used. The relative DNA quantification across treatments was evaluated using the $\Delta \Delta \mathrm{Ct}$ method (Livak \& Schmittgen 2001). Briefly, the $\Delta \mathrm{Ct}$ is calculated as the difference between the $\mathrm{Ct}$ of the investigated gene and the Ct of GAPDH in each sample (Bustin et al. 2009). The $\Delta \Delta \mathrm{Ct}$ of each investigated gene is calculated as the difference between the $\Delta \mathrm{Ct}$ in each treated sample and the $\Delta \mathrm{Ct}$ of the sample with lower gene expression (higher $\Delta \mathrm{Ct}$ ). The fold change in relative genomic DNA concentrations was calculated using the formula $2^{-\Delta \Delta C t}$. The qPCR was made in samples from animals experimentally inoculated with the two virus, wild type virus (SV-507/99) and $t k$ gene deleted virus (BoHV-5tk $\Delta$ ) using TG tissue, of the day 40 pi.

\section{Statistical analysis}

The length and titers of virus shedding of both groups were tested for normal distribution using Shapiro-Wilk test and normalized when necessary. Then, the results from the qPCR were analyzed using ANOVA test. All analyses were performed using JMP software (SAS Institute Inc., Cary, NC) and a p $<0.05$ was considered statistically significant. Data are presented as mean \pm Standard Error Mean (SEM).

\section{One step growth curve \\ RESULTS}

As the recombinant virus was amplified and characterized in bovine cells (MDBK), before inoculation in lambs we investigated its ability to replicate in ovine cells. The one step growth curve experiment performed in primary lamb testicle cells demonstrated that the recombinant BoHV$5 t k \Delta$ replicated to a similar titer and with similar kinetics to those of the parental virus (Fig.1). Similar titers and kinetics were also observed in CRIB cells, a MDBK-derived cell line. Thus, a possible impairment in replicating in lambs would not be due to a gross defect of replication in ovine cells.

\section{Acute infection}

The main virological and serological findings following inoculation of lambs with the parental virus (SV-507/99) and recombinant (BoHV-5tk $\Delta$ ) are presented in Table 1 and Figure 2. Inoculated lambs did not show systemic signs during acute infection. Body temperature remained within normal limits; food consumption and alertness were unaffected. Four of five lambs of both groups presented a mild, transient serous nasal secretion between days 2 to 6 pi. Lambs inoculated with SV-507/99 shed virus in nasal secretions up to days 9 to $12 \mathrm{pi}$, with a mean period of excretion of 11.1 days. Lambs inoculated with the recombinant BoHV-5tk $\Delta$, in general, shed virus for a shorter period of time $(\mathrm{p}<0.05)$. Virus shedding by these lambs extended up to days 6 to 12, with an average of 8.5 days. Mean virus titers shed in nasal 


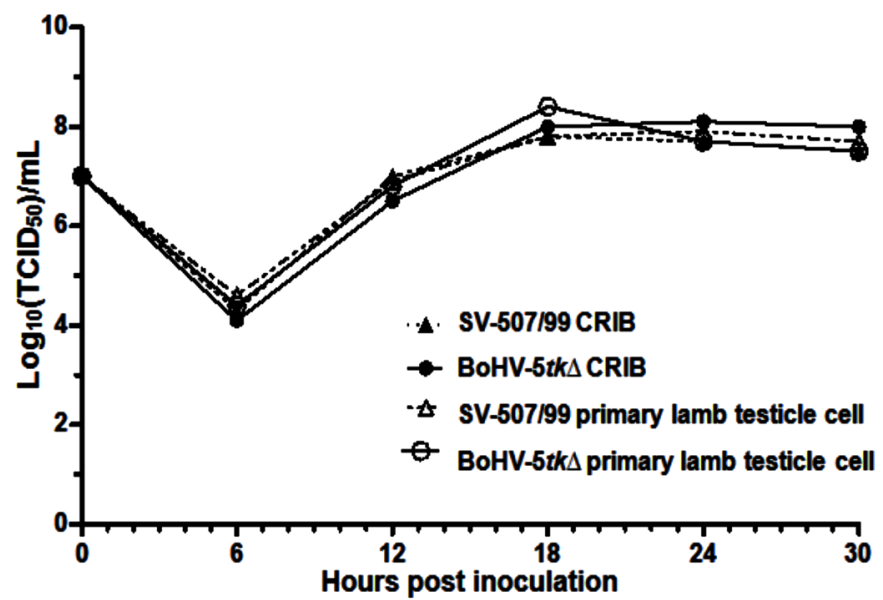

Fig.1. One step growth curve of replication of bovine herpesvirus type 5 (BoHV-5) SV-507/99 and recombinant (BoHV-5tk $\Delta$ ) in CRIB cells and primary lamb testicle cells. Cells were inoculated with a m.o.i of 5 and aliquots of culture supernatants were collected at different intervals and submitted to virus quantitation by limiting dilution. The results represent the mean of two repetitions.

secretions are presented in Fig. 2. Virus shedding peaked at day 1 pi (parental virus) and 2 pi (recombinant), and the highest titers were observed at day 4 pi for SV-507/99 $\left(10^{5.9} \mathrm{TCID}_{50} / \mathrm{ml}\right)$ and 2 pi for BoHV-5tk $\Delta\left(10^{5.1} \mathrm{TCID}_{50} / \mathrm{ml}\right)$. Virus titers were also significantly higher in secretions of lambs inoculated with the parental virus, noticeably at day $1 \mathrm{pi}$ and between days 4 at 9 pi ( $\mathrm{p}<0.01$; Fig.2). Most lambs inoculated with the parental and recombinant strains developed neutralizing antibodies at day 40 pi (Table 1). The geometric mean titer (GMT) of the parental group (2.36) was higher than the GMT of the group BoHV-5tk $\Delta$ (1.90).
Taken together, these results demonstrate that the recombinant BoHV-5tks retained the ability to replicate in the nasal mucosa of lambs. The magnitude and duration of virus replication and shedding, however, were reduced comparing to the parental strain. In other words, $t k$ deletion resulted in a moderate reduction in the replication efficiency of the recombinant virus.

\section{Latent infection}

No infectious virus was detected in nasal swabs collected from lambs inoculated with either strain at day 40 pi, demonstrating that acute virus replication had ended. Nested-PCR examination of total DNA extracted from TGs

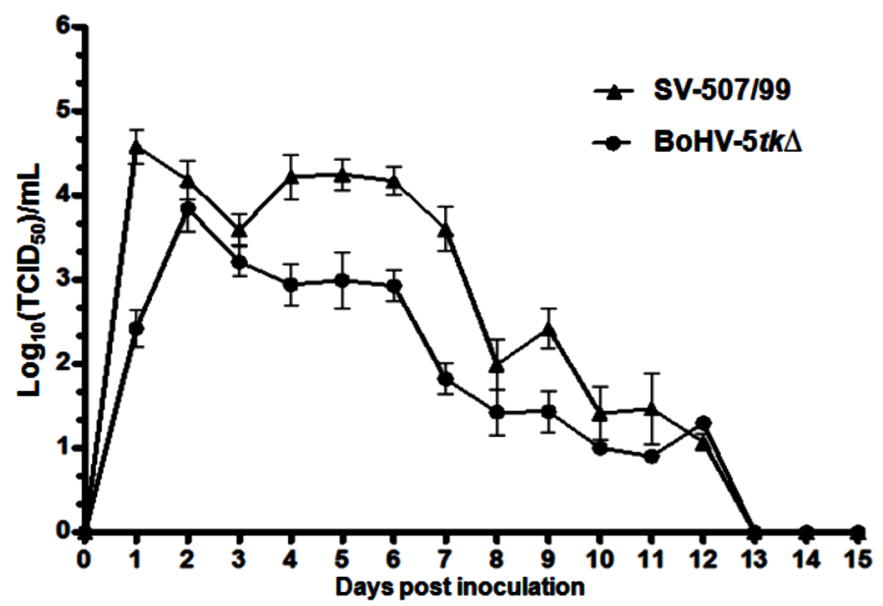

Fig.2. Virus shedding during acute infection. Mean virus titers in nasal secretions of lambs inoculated with the parental bovine herpesvirus type 5 (BoHV-5) SV-507/99 or with the recombinant $($ BoHV-5tk $\Delta)$. Data are presented as mean \pm Standard Error Mean (SEM).

Table 1. Virus shedding in nasal secretions during acute infection and virus neutralizing titers at day 40 post inoculation (pi) in lambs inoculated with parental bovine herpesvirus type 5 (BoHV-5) SV-507/99 and recombinant (BoHV-5tks)

\begin{tabular}{|c|c|c|c|c|c|c|c|c|c|c|c|c|c|c|c|c|}
\hline \multirow[t]{3}{*}{ Group } & & \multicolumn{13}{|c|}{ Virus shedding } & \multirow{2}{*}{\multicolumn{2}{|c|}{$\begin{array}{l}\text { Virus neutrali zing titers } \\
\text { Day pi }\end{array}$}} \\
\hline & \multirow[t]{2}{*}{ Animal \# } & \multicolumn{13}{|c|}{ Day post inoculation (pi) } & & \\
\hline & & 1 & 2 & 3 & 4 & 5 & 6 & 7 & 8 & 9 & 10 & 11 & 12 & 13-15 & 0 & 40 \\
\hline \multirow[t]{10}{*}{ SV-507/99 } & 1 & $4.5^{\mathrm{a}}$ & 4.3 & 2.9 & 3.1 & 4.1 & 4.1 & 2.9 & 1.3 & 2.5 & 1.0 & $-\mathrm{b}$ & - & - & $<2$ & 8 \\
\hline & 2 & 5.1 & 2.5 & 2.9 & 3.6 & 4.5 & 3.5 & 2.9 & 1.5 & - & - & - & - & - & $<2$ & 16 \\
\hline & 3 & 4.7 & 4.3 & 3.8 & 5.9 & 4.8 & 3.7 & 2.9 & 0.9 & $+^{\mathrm{c}}$ & 0.9 & - & 1.0 & - & $<2$ & 32 \\
\hline & 4 & 3.1 & 4.0 & 4.0 & 4.1 & 3.7 & 4.1 & 4.5 & 2.1 & - & - & 0.9 & - & - & $<2$ & 32 \\
\hline & 5 & 4.7 & 4.0 & 3.5 & 5.0 & 4.6 & 4.9 & 4.9 & 2.7 & 3.3 & 2.9 & - & 0.9 & - & $<2$ & 8 \\
\hline & 6 & 5.3 & 4.9 & 4.1 & 4.6 & 5.0 & 5.0 & 4.6 & 3.7 & 2.0 & 1.0 & - & 1.5 & - & $<2$ & 4 \\
\hline & 7 & 3.9 & 4.0 & 4.1 & 3.6 & 3.9 & 3.5 & 2.9 & 2.1 & 1.9 & 0.9 & - & 1.0 & - & $<2$ & 4 \\
\hline & 23 & 4.8 & 4.8 & 4.0 & 4.6 & 4.7 & 4.1 & 4.1 & 3.1 & 2.9 & 2.8 & - & 0.9 & - & $<2$ & 2 \\
\hline & 24 & 5.1 & 4.0 & 2.6 & 3.6 & 4.1 & 4.5 & 3.3 & 1.0 & 1.9 & 0.9 & - & 1.3 & - & $<2$ & 4 \\
\hline & 29 & 4.6 & 5.0 & 4.0 & 4.1 & 3.1 & 4.3 & 3.0 & 1.5 & + & 0.9 & - & 0.9 & - & $<2$ & 4 \\
\hline \multirow[t]{10}{*}{ BoHV-5tks } & 8 & 1.0 & 3.0 & 2.1 & 2.9 & 1.9 & - & 1.0 & - & - & 1.0 & - & - & - & $<2$ & 8 \\
\hline & 9 & 2.0 & 3.5 & 3.9 & 2.3 & 2.7 & 2.6 & 2.1 & 0.9 & 1.3 & - & - & - & - & $<2$ & 4 \\
\hline & 10 & 2.5 & 2.5 & 3.0 & 2.3 & 1.9 & 3.5 & - & - & - & - & - & - & - & $<2$ & 4 \\
\hline & 11 & 2.3 & 4.5 & 3.1 & 2.9 & 4.4 & 3.1 & 2.0 & 1.9 & 1.9 & 0.9 & - & 1.3 & - & $<2$ & 4 \\
\hline & 12 & 3.3 & 3.9 & 3.7 & 2.1 & 2.0 & 1.9 & 0.9 & - & - & - & 1.1 & - & - & $<2$ & 4 \\
\hline & 13 & 3.0 & 3.6 & 3.5 & 4.1 & 2.0 & 3.3 & 2.6 & 1.9 & - & - & - & - & - & $<2$ & 2 \\
\hline & 14 & 3.0 & 4.6 & 2.9 & 2.1 & 3.1 & 2.6 & 1.9 & 1.0 & 1.1 & - & + & - & - & $<2$ & 4 \\
\hline & 20 & 2.7 & 5.1 & 3.1 & 3.5 & 3.3 & 3.1 & 2.0 & - & - & - & 2.3 & - & - & $<2$ & 8 \\
\hline & 25 & 1.9 & 4.7 & 3.9 & 3.1 & 4.0 & + & 1.9 & - & - & - & 1.0 & - & - & $<2$ & 8 \\
\hline & 30 & 2.5 & 3.0 & 2.9 & 4.1 & 4.6 & 3.3 & 2.0 & - & - & 1.1 & - & - & - & $<2$ & 4 \\
\hline
\end{tabular}

${ }^{a}$ Positive sample. Viral titers expressed as $\log _{10} \mathrm{TCID}_{50} / \mathrm{mL}$. ${ }^{\mathrm{b}}$ Negative sample after inoculation in cell culture. ${ }^{\mathrm{c}}$ Positive sample after second or third passage in cell culture (titer $<10^{0.9} \mathrm{TCID}_{50} / \mathrm{mL}$ ). 
Table 2. Virus shedding in nasal secretions after dexamethasone (Dx) treatment and virus neutralizing titers at day 15 post Dx administration (pDx) in lambs inoculated with parental bovine herpesvirus type 5 (BoHV-5) SV-507/99 and recombinant (BoHV-5tks)

\begin{tabular}{|c|c|c|c|c|c|c|c|c|c|c|c|c|}
\hline \multirow[t]{3}{*}{ Group } & & \multicolumn{9}{|c|}{$\begin{array}{l}\text { Virus shedding in } \\
\text { nasal secretions }\end{array}$} & \multirow{2}{*}{\multicolumn{2}{|c|}{$\begin{array}{c}\text { Virus neutralizing } \\
\text { antibody }\end{array}$}} \\
\hline & \multirow[t]{2}{*}{ Animal \# } & \multicolumn{9}{|c|}{ Day after dexamethasone administration (pDx) } & & \\
\hline & & $0-2$ & 3 & 4 & 5 & 6 & 7 & 8 & 9 & $10-15$ & 0 & 15 \\
\hline \multirow[t]{4}{*}{ SV-507/99 } & 1Dx & $-\mathrm{a}$ & $2.0^{\mathrm{b}}$ & 1.3 & $+^{\mathrm{c}}$ & + & 1.8 & 1.3 & - & - & 8 & 16 \\
\hline & 2Dx & - & - & - & 1.6 & 1.8 & 1.9 & 2.0 & - & - & 32 & 16 \\
\hline & $5 \mathrm{Dx}$ & - & - & 1.3 & 3.5 & + & + & 1.0 & - & - & 32 & 32 \\
\hline & $6 \mathrm{Dx}$ & - & - & - & 4.1 & 3.5 & 2.5 & 2.6 & 1.5 & - & 8 & 8 \\
\hline \multirow[t]{4}{*}{ BoHV-5tks } & $8 D x$ & - & - & - & - & - & - & - & - & - & 8 & 2 \\
\hline & 10Dx & - & - & - & - & - & $(+)^{d}$ & - & - & - & 4 & 4 \\
\hline & 11Dx & - & - & - & - & - & - & $(+)$ & - & - & 4 & 4 \\
\hline & $12 \mathrm{Dx}$ & - & - & - & $(+)$ & - & $(+)$ & $(+)$ & $(+)$ & - & 2 & 2 \\
\hline
\end{tabular}

$\overline{{ }^{a} \text { Negative sample. }{ }^{b}}$ Positive sample. Viral titers expressed as $\log _{10} \mathrm{TCID}_{50} / \mathrm{mL}^{\mathrm{c}}$ Positive sample after second or third passage in cell culture (titer $<10^{0.9} \mathrm{TCID}_{50} / \mathrm{mL}$ ). ${ }^{\mathrm{d}}$ Samples negative by virus isolation - positive by nested-PCR.

revealed the presence of viral DNA in the ganglia of all inoculated lambs, regardless the group (data not show). No infectious virus was detected in these portions upon three passages of tissue homogenates in CRIB cells, confirming the status of latent infection. These results demonstrated that the parental virus and the recombinant BoHV-5tk $\Delta$ established latent infection with the same frequency in the TGs of inoculated lambs. In other words, $t k$ deletion (and the reduced acute replication that ensued) apparently did not adversely affect the ability of the recombinant to establish latent infection in nerve ganglia of lambs.

As acute replication of the recombinant virus in the periphery was reduced compared to the parental virus, we then sought to compare the amount of latent viral DNA present in TG of both groups. This approach would determine whether $t k$ deletion would affect the efficiency of colonization of the ganglia with latent DNA. To this end, we used a real time qPCR to quantitate wildtype and recombinant latent DNA in the TGs. The results presented in Figure 3

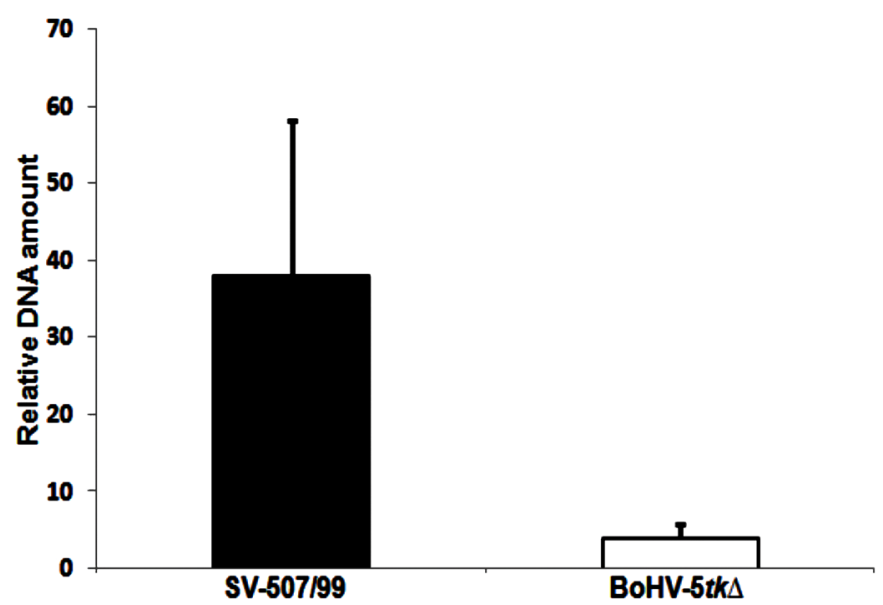

Fig.3. Relative viral DNA amount in trigeminal ganglia of lambs inoculated with bovine herpesvirus type 5 (BoHV-5) strain SV-507/99 and a recombinant BoHV-5tk $\Delta$. The relative DNA quantification was determinate using $\Delta \Delta \mathrm{Ct}$ method and GAPDH as a housekeeping gene. Data are presented as mean \pm Standard Error Mean(SEM). show that the amount of recombinant virus DNA in TGs of 10 lambs was approximately 9.7-fold lower than the amount of parental virus DNA in the respective 10 animals. Thus, although the recombinant was still able to consistently colonize the TGs, the overall amount of latent DNA was highly reduced $(\mathrm{p}<0.001)$ compared to the parental strain. In other words, $t k$ gene deletion did not affect the ability of the recombinant to establish latency but it did reduce the efficiency of colonization of TGs with latent viral DNA.

\section{Reactivation of latent infection}

Following Dx administration - starting at day 40pi -, all four lambs inoculated with parental strain shed infectious virus in nasal secretions (mean duration $=5$ days [4-6]) (Table 2). Shedding was first detected at day 3 and lasted up to day $9 \mathrm{pDx}$ in one lamb. The peak in virus titers was observed at days 5 and $6 \mathrm{pDx}$, with titers reaching $10^{4.1} \mathrm{TCID}_{50} /$ $\mathrm{mL}$. No systemic or neurological signs were recorded in these animals. In contrast, nasal secretions from BoHV$5 t k \Delta$-inoculated lambs were negative for infectivity upon virus inoculation in cell cultures (Table 2). These results indicated lack of reactivation by the recombinant virus since no infectious virus was recovered from nasal swabs.

As to further investigate reactivation of the recombinant virus, nasal swabs collected after Dx treatment, were submitted to a PCR for a target sequence within the gB gene. Surprisingly and contrasting with negative results in virus isolation, swabs of 3 out of 4 lambs were positive for viral DNA (Table 2). Two of these animals (\# 2 and 5) were positive in only one collection (days 7 and $8 \mathrm{pDx}$, respectively); animal \# 6 yielded positive results in four days.

An additional PCR designed to amplify a genome region contained within the $t k$ deletion was then used to discard a possible cross-contamination with the parental virus. This PCR confirmed that the viral DNA present in swabs was indeed that of the recombinant virus (Fig.4). These results contrasted with the results of virus isolation and indicated reactivation of the recombinant virus.

The discrepant results of virus isolation and PCR in these samples may reflect a low sensitivity of our virus iso- 


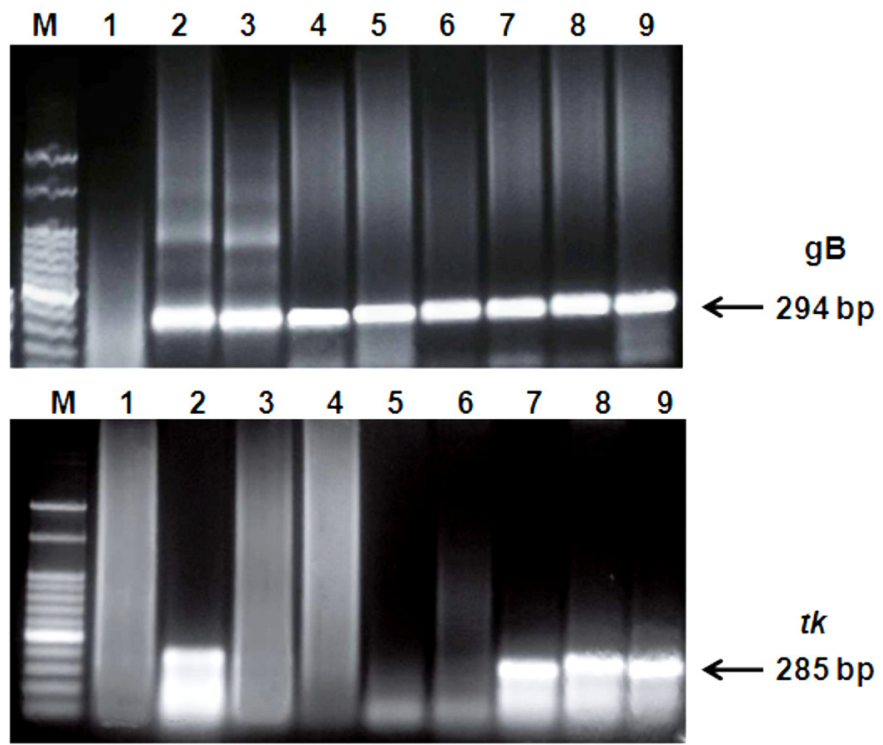

Fig.4. Detection of viral DNA by PCR in nasal swabs of lambs submitted to dexamethasone treatment. Top panel: nested PCR for glycoprotein B (gB) gene. Lower panel: PCR for thymidine kinase $(t k)$ gene, where a positive reaction indicates the presence of entire $t k$ gene. Lane M: Molecular weight marker; lane

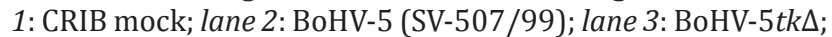
lanes 4, 5, 6: swabs of animals inoculated with BoHV-5tks; lanes 7, 8, 9: swabs of animals inoculated with parental virus (SV-507/99).

lation protocol and/or virus neutralization by antibodies present in nasal secretions. In any case, these results demonstrate that the recombinant BoHV-5tk $\Delta$ was able to reactivate - even at very low levels - following Dx treatment. Hence, TK activity seems not to be absolutely required for reactivation of latent infection by BoHV-5 in lambs.

\section{DISCUSSION}

Our results demonstrate that BoHV-5 TK activity is not essential for the establishment of latent infection, but is important for efficient colonization of nerve ganglia with latent viral DNA. The recombinant BoHV-5tks colonized the TGs with the same frequency, yet with approximately 9.7-fold less latent viral DNA than did the parental strain. Low level of reactivation of BoHV- $5 t k \Delta$ was detected after Dx treatment, indicating that the enzyme activity is important - but not essential - for reactivation in lambs. As these results were obtained in lambs, they need to be validated in the natural hosts.

The ability of the recombinant BoHV- $5 t k \Delta$ to replicate in cell culture was not adversely affected (Fig. 1), as previously described in bovine and rabbit cells (Brum et al. 2010b, Silva et al. 2010). Replication of BoHV-5tks in the nasal mucosa of lambs, however, was significantly reduced (Table 1, Fig.2), confirming previous observations in rabbits (Silva et al. 2010) and calves (Santos et al. 2011) and extending previous observations with $t k$-deleted PRV and BoHV-1 strains in pigs and calves, respectively (Kaashoek et al. 1996, Ferrari et al. 1998). Indeed, TK-defective PRV, BoHV-1 and BoHV-5 usually show a reduced ability - to various extents - to replicate in peripheral tissues compared to TK positive counterparts (Kaashoek et al. 1996, Ferrari et al. 1998, 2000, Silva et al. 2010, Santos et al. 2011).

Although the recombinant replicated to lower titers than the parental strain in the nose during acute infection, it was still able to establish latent infection in all inoculated animals. These data would suggest that $t k$ deletion - in spite of reducing acute virus replication at periphery - did not drastically reduce the ability of the virus to establish latency. However, qPCR analysis showed a 9.7-fold reduction in the amount of recombinant virus DNA in TGs compared to the parental strain. Thus, $t k$ deletion did not abolish the ability of the virus to establish latency, but resulted in a reduced colonization of TGs. We hypothesize that the reduced colonization of TGs with BoHV-5tk $\Delta$ was predominantly a consequence of the decreased virus replication/load in the nose during acute infection rather than due to a reduced ability to replicate in neurons prior to the establishment of latent infection. Conceivably, a deficient virus replication during primary infection would result in reduced virus loads to invade the nervous system and colonize the nerve ganglia. Previous studies with HSV-1 in mouse models have shown that the establishment of latent infection by TK-defective mutants was 6 - to 50 -fold reduced comparing to the wildtype strains, as ascertained by the total of viral genomes, latently infected neurons and neurons expressing the latency related transcripts (Coen et al. 1989, Katz et al. 1990, Thompson \& Sawtell 2000, Chen et al. 2004). On the other hand, slight or pronounced reduction in virus replication during acute infection had no apparent effect on the ability of the recombinant BoHV-5tk $\Delta$ to produce latency in calves and rabbits (Silva et al. 2010, Santos et al. 2011) and of TK- defective PRV strains to establish latent infection in young pigs (Mengeling et al. 1992, Volz et al. 1992). Thus, lack of viral TK activity would reduce replication at peripheral sites but not to an extent that would abolish the ability to establish latent infection. Hence, viral TK activity is important for efficient acute replication in peripheral tissues which, in turn, would directly influence the level of colonization of ganglia with latent DNA.

The absence of infectious recombinant virus in nasal secretions following Dx treatment was somehow expected and would meet the general concept that TK-defective human and animal alphaherpesviruses are severely impaired in reactivating latent infection (Coen et al. 1989, Tenser et al. 1989, Ferrari et al. 2000, Chen et al. 2004). Whether the absence of infectious virus was derived from an inherent inability of BoHV-5tk $\Delta$ to reactivate or a consequence of the reduced colonization of TGs, or a combination of both, is unclear. In a mouse model, $t k$-negative HSV mutants did not reactivate even when their latent viral loads were comparable to those of the parental strains, indicating that reduced colonization of nerve ganglia does not suffice to explain failure to reactivate (Chen et al. 2004).

The role of alphaherpesvirus-encoded TK activity in virus reactivation is far more controversial. A number of studies have shown that truly TK negative HSV mutants derived from laboratory strains do not reactivate from nerve ganglia (Tenser \& Edris 1987, Coen et al. 1989, Tenser et al. 1996, Chen et al. 2004), yet some mutants derived from clinical isolates mi- 
ght reactivate inefficiently (Horsburgh et al. 1998, Griffiths et al. 2003). Conflicting findings have also been reported for BoHV-1 and PRV tk deletion mutants, and both reactivation (Mengeling et al. 1992, Whetstone et al. 1992) and lack of reactivation have been reported (Mengeling 1991, Kaashoek et al. 1996, Ferrari et al. 2000). Most of these discrepancies likely reflect differences in virus species, strains, animals (natural hosts versus laboratory models) and experimental procedures (e.g. in vivo versus in vitro reactivation). Regardless, the general concept is that herpesvirus TK activity is crucial for efficient reactivation such truly $t k$-null mutants do not reactivate - or reactivate very poorly - from nerve ganglia (Coen et al. 1989, Tenser et al. 1996, Chen et al. 2004).

The detection of BoHV-5tk $\Delta$ DNA by PCR in a few nasal swabs after Dx treatment indicated that some level of reactivation did occur. Although this is an unusual event for many $t k$ negative alphaherpesviruses examined to date, low level of Dx-induced reactivation was also observed for this recombinant in calves (Santos et al. 2011). Along this line, viral TK activity as low as $0.09 \%$ of the wt levels appeared sufficient to support low levels of reactivation of $t k$ negative HSV mutants in a mouse model (Besecker et al. 2007). Taken together, these data demonstrate that BoHV$-5 t k \Delta$ is severely, but not completely impaired, in its ability to reactivate latent infection.

Trying to reconcile these findings, we hypothesize that

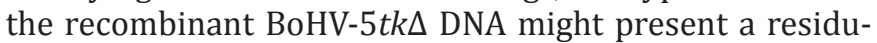
al ability to reactivate latent infection in neural tissue. It is also possible that reactivation of the recombinant occurred in lymphoid tissue, a secondary site of latency/persistence of PRV (Wheeler \& Osorio 1991), BoHV-1 (Inman et al. 2002) and BoHV-5 (Cadore G. unpublished observations). Reinforcing the second hypothesis, latent BoHV-1 present in tonsils of latently infected calves was shown to reactivate and lead to productive virus replication upon Dx treatment and explant cultures in vitro (Inman et al. 2002, Perez et al. 2002). Either hypotheses would only be supported by

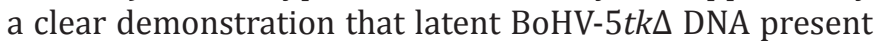
in nerve ganglia and/or in lymphoid tissue is reactivatable upon corticosteroid treatment.

Lastly, the clear demonstration that virus undetectable by virus isolation may be present in secretions of animals submitted to corticosteroid treatment recommends a reexamination of the indicators of virus reactivation in studies of alphaherpesvirus reactivation. As small amounts of virus may be rendered non-infectious by neutralizing antibodies present in secretions (Pastoret \& Thiry 1985), the absence of infectivity should not be taken as the sole and definitive proof of lack of reactivation.

In summary, our results demonstrated that BoHV-5 encoded TK activity is not required for the establishment of latent infection, but is necessary for efficient colonization of TGs (likely through enhanced replication in peripheral tissue) and is required for efficient virus reactivation in a lamb model. The presence of recombinant viral DNA in a few swabs collected after Dx treatment indicates that virus reactivation - even at very low levels - took place. Whether reactivation occurred in TGs or in other neural or non-neural sites is uncertain.

\section{REFERENCES}

Belknap E.B., Collins J.K., Ayers V.K. \& Schultheiss P.C. 1994. Experimental infection of neonatal calves with neurovirulent bovine herpesvirus type-5 (BHV-5). Vet. Pathol. 31:358-365.

Besecker M.I., Furness C.L., Coen D.M. \& Griffiths A. 2007. Expression of extremely low levels of thymidine kinase from an acyclovir-resistant herpes simplex virus mutant supports reactivation from latently infected mouse trigeminal ganglia. J. Virol. 81(15):8356-8360.

Brum M.C.S., Weiblen R., Flores E.F. \& Chowdhury S.I. 2010a. Construction and growth properties of bovine herpesvirus type 5 recombinants defective in the glycoprotein E or thymidine kinase gene or both. Braz. J. Med. Biol. Res. 43:217-224.

Brum M.C.S., Santos C.M.B., Weiblen R. \& Flores E.F. 2010b. Selection and characterization of brivudin resistant bovine herpesvirus type 5. Braz. J. Microbiol. 41:124-132.

Bustin S.A., Benes V., Garson J.A., Hellemans J., Huggett J., Kubista M., Mueller R., Nolan T., Pfaffl M.W., Shipley G.L., Vandesompele J. \& Wittwer C.T. 2009. The MIQE guidelines: minimum information for publication of quantitative real-time PCR experiments. Clin. Chem. 55(4):611-622.

Cadore G.C., Anziliero D., Weiblen R. \& Flores E.F. 2011. Reactivation and distribution of bovine herpesvirus 5 DNA in the brain of latently infected lambs. Pesq. Vet. Bras. 31(12):1090-1096.

Caron L., Flores E.F., Weiblen R., Scherer C.F.C., Irigoyen L.F., Roehe P.M., Odeon A. \& Sur J.-H. 2002. Latent infection by bovine herpesvirus type5 in experimentally infected rabbits: virus reactivation, shedding and recrudescence of neurological disease. Vet. Microbiol. 84(4):285-295.

Chen S.H., Pearson A. \& Coen D.M. 2004. Failure of thymidine kinase-negative herpes simplex virus to reactivate from latency following efficient establishment. J. Virol. 78:520-523.

Chowdhury S.I. 1996. Construction and characterization of an attenuated bovine herpesvirus type 1 (BHV-1) recombinant virus. Vet. Microbiol. 52:13-23.

Chowdhury S.I., Lee B.J., Mosier D., Sur J.H., Osorio F.A., Kennedy G. \& Weiss M.L. 1997. Neuropathology of bovine herpesvirus type 5 (BHV-5) meningo-encephalitis in a rabbit seizure model. J. Comp. Pathol. 117:295310.

Coen D.M., Kosz-Vnenchak M., Jacobson J.G., Leib D.A., Bogard C.L., Schaffer P.A., Tyler K.L. \& Knipe D.M. 1989. Thymidine kinase-negative herpes simplex virus mutants establish latency in mouse trigeminal ganglia but do not reactivate. Proc. Natl Acad. Sci. USA. 86:4736-4740.

Delhon G., Moraes M.P., Lu Z., Afonso C.L., Flores E.F., Weiblen R., Kutish G.F. \& Rock D.L. 2003. Genome of bovine herpesvirus 5. J. Virol. 77:1033910347.

Diel D.G., Almeida S.R., Brum M.C., Dezengrini R., Weiblen R. \& Flores E.F. 2007. Acute and latent infection by bovine herpesvirus type 5 in experimentally infected goats. Vet. Microbiol. 121:257-267.

Ferrari M., Gualandi G.L., Corradi A., Monaci C., Romanelli M.G., Tosi G. \& Cantoni A.M. 1998. Experimental infection of pigs with a thymidine kinase negative strain of pseudorabies virus. Comp. Immunol Microbiol. Infect. Dis. 21:291-303.

Ferrari M., Mettenleiter T.C., Romanelli M.G., Cabassi E., Corradi A., Dal Mas N. \& Silini R. 2000. A comparative study of pseudorabies virus (PRV) strains with defects in thymidine kinase and glycoprotein genes. J. Comp. Pathol. 123:152-163.

Flores E.F., Weiblen R., Vogel F.S.F., Dezengrini R., Almeida S.R., Spilki F.R. \& Roehe P.M. 2009. Experimental neuropathogenesis of bovine herpesvirus 5 infection in rabbits. Pesq. Vet. Bras. 29:1-16.

Griffiths A., Chen S.H., Horsburgh B.C. \& Coen D.M. 2003. Translational compensation of a frameshift mutation affecting herpes simplex virus thymidine kinase is sufficient to permite reactivation from latency. J. Virol. 77:4703-4709.

Horsburgh B.C., Chen S.H., Hu A., Mulamba G.B., Burns W.H. \& Coen D.M. 1998. Recurrent acyclovir-resistant herpes simplex virus in an immunocompromised patient: can strain differences compensate for loss of thymidine kinase in pathogenesis? J. Infect. Dis. 178:618-625. 
Inman M., Lovato L., Doster A. \& Jones C. 2002. A mutation in the latency related gene of bovine herpesvirus 1 interferes with the latency-reactivation cycle of latency in calves. J. Virol. 76:6771-6779.

Kaashoek M.J., Van Engelenburg F.A., Moerman A., Gielkens A.L., Rijsewijk F.A. \& Van Oirschot J.T. 1996. Virulence and immunogenicity in calves of thymidine kinase- and glycoprotein E-negative bovine herpesvirus 1 mutants. Vet. Microbiol. 48:143-53.

Kahrs R.F. 2001. Infectious bovine rhinotrachitis and infectious pustular vulvovaginitis, p.159-170. In: Ibid. (Ed.), Viral Disease of Cattle. Iowa State University Press, Ames.

Katz J.P., Bodin E.T. \& Coen D.M. 1990. Quantitative polymerase chain reaction analysis of herpes simplex virus DNA in ganglia of mice infected with replication-incompetent mutants. J. Virol. 64:4288-4295.

Kit S. 1985. Thymidine kinase. Microbiol. Sci. 2(12):369-375.

Livak K.J. \& Schmittgen T.D. 2001. Analysis of relative gene expression data using real-time quantitative PCR and the $2^{-\Delta \Delta \mathrm{Ct}}$ method. Methods 25(4):402-408.

Mengeling W.L. 1991. Virus reactivation in pigs latently infected with a thymidine kinase negative vaccine strain of pseudorabies virus. Arch. Virol. 120:57-70.

Mengeling W.L., Lager K.M., Volz D.M. \& Brockmeier S.L. 1992. Effect of various vaccination procedures on shedding, latency, and reactivation of attenuated and virulent pseudorabies virus in swine. Am. J. Vet. Res. 53:2164-2173.

Pastoret P. \& Thiry E. 1985. Diagnosis and prophylaxis of infectious bovine rhinotracheitis: the role of virus latency. Comp. Immunol. Microbiol. Infect. Dis. 8:35-42.

Perez S.E., Bretschneider G., Leunda M.R., Osorio F.A., Flores E.F. \& Odeon A.C. 2002. Primary infection, latency, and reactivation of bovine herpesvirus type 5 in the bovine nervous system. Vet. Pathol. 39:437-444.

Perez S.E., Vagnozzi A., Sur J.H., Odriozola E., Campero C.M. \& Odeón A.C. 2003. Análisis restrospectivo de casos com diagnóstico de necrosis cerebrocortical y su relación con herpesvirus bovino tipo 5. Revta Argent. Microbiol. 35:6973.

Reed L.J. \& Muench H. 1938. A simple method for estimating fifty per cent end points. Am. J. Hyg. 27:493-497.

Rissi D.R., Pierezan F., Silva M.S., Flores E.F. \& Barros C.S. 2008. Neurological disease in cattle in southern Brazil associated with bovine herpesvirus infection. J. Vet. Diagn. Invest. 20:346-349.

Rock D. 1994. Latent infection with bovine herpesvirus type-1. Semin. Virol. 5:233-240.

Roizman B., Desrosiers R.C., Fleckenstein B., Lopez C., Minson A.C. \& Studdert M.J. 1992. The family Herpesviridae: An update. Arch. Virol. 123:432-445.

Salvador S.C., Lemos R.A.A., Riet-Correa F., Roehe P.M. \& Osório A.L.A.R.
1998. Meningoencefalite em bovinos causada por herpesvírus bovino-5 no Mato Grosso do Sul e São Paulo. Pesq. Vet. Bras. 18:76-83.

Santos C.M.B., Anzilliero D., Bauermann D., Brum M.C.C., Weiblen R. \& Flores E.F. 2011. Experimental infection of calves with recombinants of bovine herpesvirus 5 defective in glycoprotein $\mathrm{E}$ ( $\mathrm{gE}$ ), thymidine kinase (TK) and both gE/TK. Pesq. Vet. Bras. 31(4):319-325.

Silva A.M., Weiblen R., Irigoyen L.F., Roehe P.M., Sur H.J., Osorio F.A. \& Flores E.F. 1999. Experimental infection of sheep with bovine herpesvirus type-5 (BHV-5). Vet. Microbiol. 66:89-99.

Silva S.C., Brum M.C., Weiblen R., Flores E.F. \& Chowdhury S.I. 2010. A bovine herpesvirus 5 recombinant defective in the thymidine kinase (TK) gene and a double mutant lacking TK and the glycoprotein E gene are fully attenuated for rabbits. Braz. J. Med. Biol. Res. 43:150-159.

Tenser R.B. 1991. The role of herpes simplex virus thymidine kinase expression in pathogenesis and latency. Intervirology 32:76-92.

Tenser R.B. \& Edris W.A. 1987. Trigeminal ganglion infection by thymidine kinase-negative mutants of herpes simplex virus after in vivo complementation. J. Virol. 61:2171-2174.

Tenser R.B., Miller R.L. \& Rapp F. 1979. Trigeminal ganglion infection by thymidine kinase-negative mutants of herpes simplex virus. Science 205:915-917.

Tenser R.B., Hay K.A. \& Edris W.A. 1989. Latency-associated transcript but not reactivatable virus is present in sensory ganglion neurons after inoculation of thymidine kinase negative mutants of herpes simplex virus type 1. J. Virol. 63:2861-2865.

Tenser R.B., Gaydos A. \& Hay K.A. 1996. Reactivation of thymidine kinase-defective herpes simplex virus is enhanced by nucleoside. J. Virol. 70:1271-1276.

Thompson R.L. \& Sawtell N.M. 2000. Replication of herpes simplex virus type 1 within trigeminal ganglia is required for high frequency but not high viral genome copy number latency. J. Virol. 74:965-974.

Thrusfield M. 2005. Veterinary Epidemiology. $3^{\text {rd }}$ ed, Oxford, Blackwell Science. 610p.

Vogel F.S., Caron L., Flores E.F., Weiblen R., Winkelmann E.R., Mayer S.V. \& Bastos R.G. 2003. Distribution of bovine herpesvirus type 5 DNA in the central nervous systems of latently, experimentally infected calves. J. Clin. Microbiol. 41:4512-4520.

Volz D.M., Lager K.M. \& Mengeling W.L. 1992. Latency of a thymidine kinase-negative pseudorabies vaccine virus detected by the polymerase chain reaction. Arch. Virol. 122:341-348.

Wheeler J.G. \& Osorio F.A. 1991. Investigation of sites of pseudorabies virus latency, using polymerase chain reaction. Am. J. Vet. Res. 52(11):17991803.

Whetstone C.A., Miller J.M., Seal B.S., Bello L.J. \& Lawrence W.C. 1992. Latency and reactivation of a thymidine kinase-negative bovine herpesvirus 1 deletion mutant. Arch. Virol. 122:207-214. 